\title{
AN UPDATE ON ANOMALOUSLY WHITE CETACEANS, INCLUDING THE FIRST ACCOUNT FOR THE PANTROPICAL SPOTTED DOLPHIN (STENELLA ATTENUATA GRAFFMANI)
}

\author{
Dagmar Fertl ${ }^{1,2}$, Nélio B. Barros ${ }^{3}$, Richard A. Rowlett ${ }^{4}$, Susan Estes ${ }^{5}$ and Michael Richlen ${ }^{6}$
}

Keywords: pigmentation, pantropical spotted dolphin, common bottlenose dolphin, Gulf of Mexico, Panama.

Mammalian color is almost entirely dependent on presence (or absence) of the pigment melanin in the skin, hair, and eyes. Hypo-pigmented (anomalously white) individuals are often presumed to be true albinos; however, pigmentation patterns should not be the only criterion (Fertl and Rosel, 2002). Anomalously white individuals have been reported for a number of cetacean and pinniped species (Fertl and Rosel, 2002); Fertl et al. (1999) reviewed the infrequent occurrence of this aberrant pigmentation for 20 cetacean species. Additional records have since become available, including the first for the blue whale (Balaenoptera musculus) (Chandler et al., 20017) and details of an all-white humpback whale (Megaptera novaeangliae) still living in Australian waters (Forestell et al., 2001). We present the first known account for an allwhite pantropical spotted dolphin (Stenella attenuata graffmani), off the Pacific coast of Panama, as well as a subsequent record for Gulf of Mexico common bottlenose dolphins (Tursiops truncatus).

\section{Pantropical Spotted Dolphin}

An all-white "coastal" pantropical spotted dolphin (Stenella attenuata graffmani) calf was sighted and photographed in a school of about 60 individuals (primarily mothers with calves, and juveniles) in shallow coastal waters off western Panama, near Isla de Coiba $\left(07^{\circ} 18^{\prime} \mathrm{N}, 81^{\circ} 56^{\prime} \mathrm{W}\right)$, on 20 November 2003 from NOAA Ship McArthur II (Figure 1).

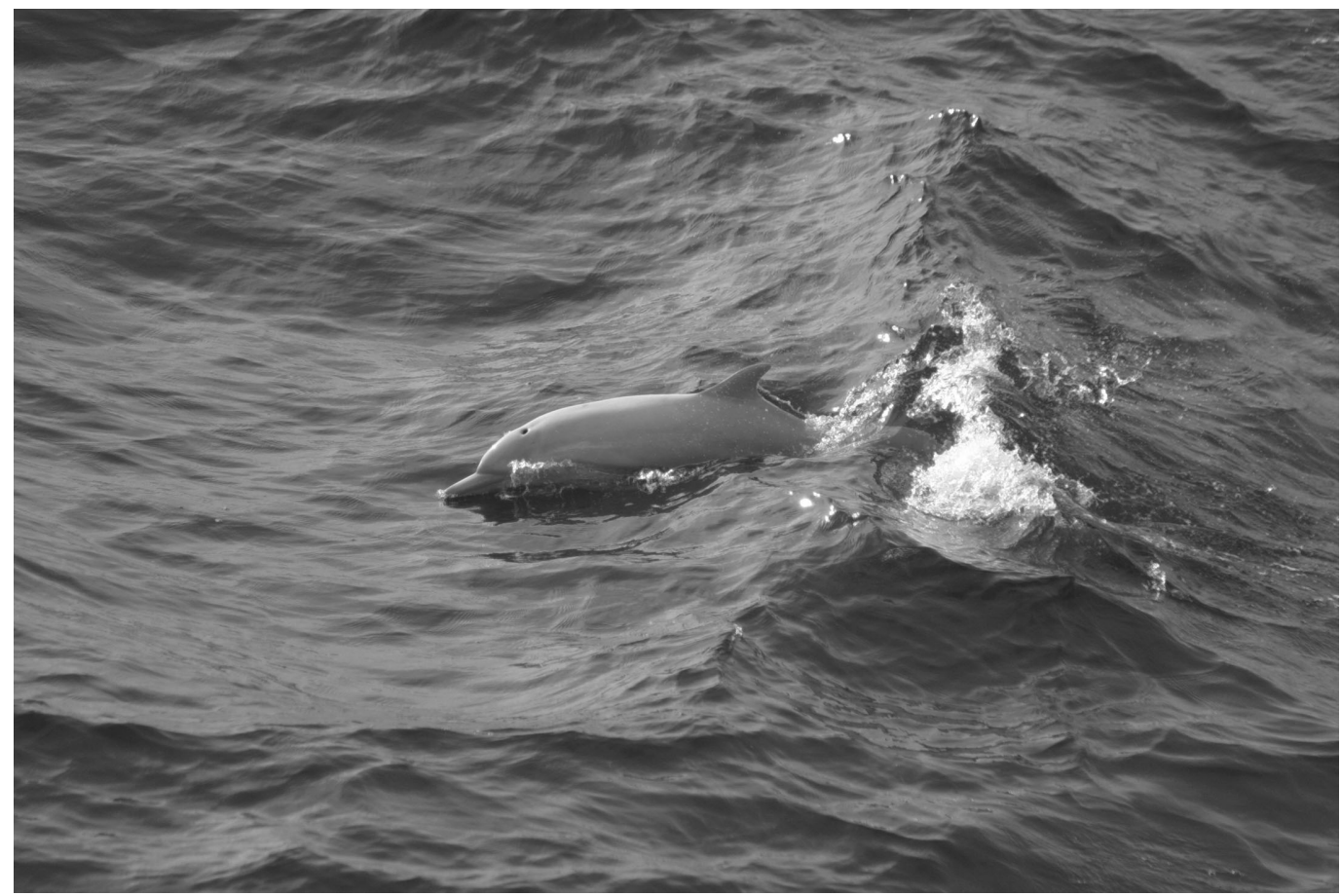

Figure 1. Anomalously white pantropical spotted dolphin (Stenella attenuata graffmani) photographed off the Pacific coast of Panama. (Photo: Michael Richlen).

\footnotetext{
${ }^{1}$ Geo-Marine, Inc. 550 East $15^{\text {th }}$ Street, Plano, Texas 75074 USA.

${ }^{2}$ Corresponding author: dfertl@geo-marine.com.

${ }^{3}$ Center for Marine Mammal and Sea Turtle Research, Mote Marine Laboratory. 1600 Ken Thompson Parkway, Sarasota, Florida 342361004 USA.

${ }^{4}$ Southwest Fisheries Science Center, NOAA, National Marine Fisheries Service. 8604 La Jolla Shores Drive, La Jolla, California 92037 USA. ${ }^{5} 8753$ Barcin Circle, Riverview, Florida 33569-4951 USA.

${ }^{6} 2469$ 168th Place, NE, Bellevue, Washington 98008 USA.

${ }^{7}$ Chandler, T., Calambokidis, J. and Sears, R. (2001) First report on sightings of a white blue whale. Page 41 in Abstracts, XIV Biennial Conference on the Biology of Marine Mammals, 28 November - 03 December, Vancouver, British Columbia, Canada.
} 
The estimated $1.7 \mathrm{~m}$ juvenile female was uniformly pinkishwhite and possessed the slightest hint of the characteristic caped pigmentation pattern. Examination of numerous photos, however, could not confirm with absolute certainty the presence of a "pink" eye. The eyes were curiously closed, but the eyelids were indeed pink. The juvenile maintained constant close association with a normally pigmented adult and was quite exuberant as it repeatedly leaped before the boat's bow on several occasions. A large fleshy-bodied remora (family Echeneididae) was also attached to the dolphin's left side. It was not possible to identify the remora to species; as noted by Fertl and Landry $(1999,2002)$, species identification in remoras is difficult without the actual specimen in hand.

\section{Common bottlenose dolphin}

On 13 September 2003 at 08:30h, shrimp fishermen observed an all-white (appeared bright pink) calf with red eyes accompanied by a normally pigmented adult within a group of approximately $40+$ dolphins $77 \mathrm{~km}$ south of Galveston, Texas $\left(28^{\circ} 47^{\prime} \mathrm{N}, 94^{\circ} 15^{\prime} \mathrm{W}\right)$ (Figure 2$)$. The animals were determined to be common bottlenose dolphins, due to species characteristics visible in photographs of the mother/calf pair, including their short beaks and the apparent absence of spotting on the adult (as well as other individuals in the group), as well as based on habitat characteristics where they were observed waters with a bottom depth of approximately $30 \mathrm{~m}$. The calf's small size suggests that it is a young-of-the-year, possibly born in March to April, when a peak in calving seasonality and the highest incidence in neonate strandings are observed along the Texas coast (Jones, 1988; Fernandez and Hohn, 1998; Worthy, 1998).

The white dolphin calf was spotted from the R/V Retriever (a $23 \mathrm{~m}$ shrimp boat), when it was underway (i.e., not trawling) from one shrimping location to another. The crew was sorting shrimp from the bycatch while the boat was underway, constantly discarding bycatch over the side of the boat. While working, one crew member was periodically watching dolphins feeding on the bycatch. The boat was stopped as soon as the white calf was observed, although the shrimpers continued to discard bycatch. The presumed mother/calf pair was observed on the outskirts of the dolphin group, furthest from the boat; their closest approach was approximately $9 \mathrm{~m}$ from the boat, although other dolphins in the group approached much closer at times. The dolphin group was observed for approximately 30 minutes before the shrimpers ran out of fish to be discarded and the boat left the area. A white dolphin calf has seen been resighted on many occasions in the same general vicinity of the original sighting, as recently as August 2004. It is quite probable that these sightings refer to the same individual, especially since shrimpers who sighted the calf originally commented on the larger size of the individual upon the resights. This observation is of particular interest in part due to survivability of this aberrantly pigmented individual, as well as its apparent consistent use of the same general area.

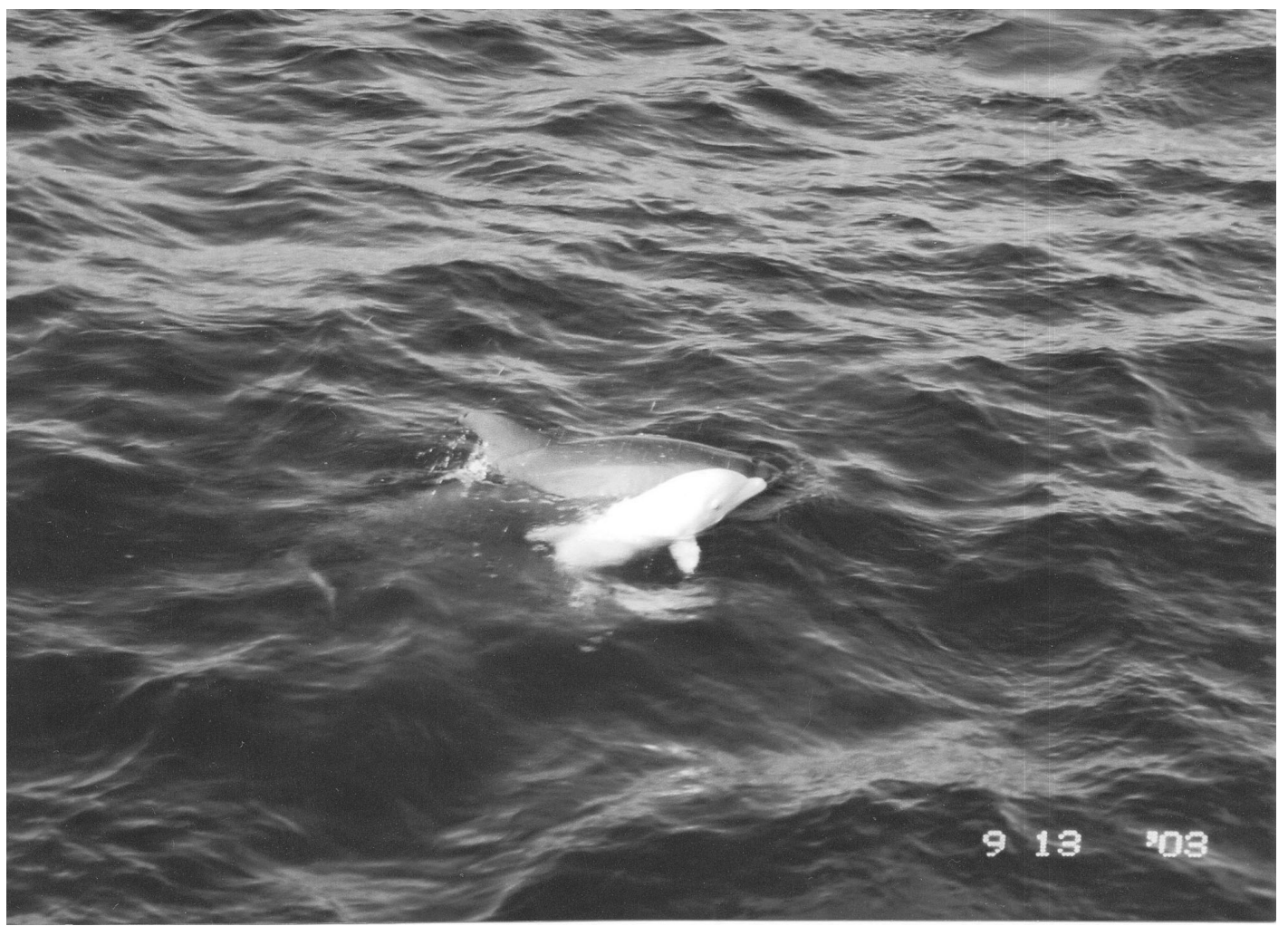

Figure 2. Anomalously white common bottlenose dolphin (Tursiops truncatus) calf photographed off Texas coast in the northern Gulf of Mexico (Photo: Susan Estes). 
Little is known about how common anomalously white cetaceans are, or the costs associated with this aberrant pigmentation, such as visual impairment, conspicuousness to predators, thermoregulatory limitations or the ontogenetic survival rates of those presenting the condition (Fertl and Rosel, 2002). We encourage others to publish their observations so that a proper assessment and further insights into the ecological and physiological implications of this condition in cetaceans can be evaluated in the future.

Table 1. Records of Anomalously White Cetaceans.

\begin{tabular}{|c|c|c|c|}
\hline SPECIES & DATE & LOCATION & REFERENCES \\
\hline \multirow{3}{*}{$\begin{array}{l}\text { Blue whale } \\
\text { (Balaenoptera musculus) }^{8}\end{array}$} & 1997 & Gulf of California, Mexico & Chandler et al. (2001) 7,9 \\
\hline & 1999 & $\begin{array}{l}\text { Santa Barbara Channel, } \\
\text { California, USA }\end{array}$ & Chandler et al. (2001) 7,9 \\
\hline & $\begin{array}{l}\text { Summer } \\
2000\end{array}$ & Southern California, USA & Chandler et al. (2001) 7,9 \\
\hline $\begin{array}{l}\text { Gray whale } \\
\text { (Eschrichtius robustus) }\end{array}$ & $\begin{array}{l}\text { February } \\
2003\end{array}$ & $\begin{array}{l}\text { Guerrero Negro Lagoon and } \\
\text { Laguna Ojo de Liebre, Baja } \\
\text { California, Mexico }\end{array}$ & Jones $(2003)^{10}$ \\
\hline $\begin{array}{l}\text { Heaviside's dolphin } \\
\text { (Cephalorynchus heavisidii) }\end{array}$ & $\begin{array}{l}\text { October } \\
2000\end{array}$ & Lüderitz, Namibia, Africa & Cole $(2000)^{9,11}$ \\
\hline $\begin{array}{l}\text { Pantropical spotted dolphin } \\
\text { (Stenella attenuata graffmani) }\end{array}$ & $\begin{array}{l}20 \text { November } \\
2003\end{array}$ & $\begin{array}{l}\text { Off the Pacific coast of Panama, } \\
\text { Central America }\end{array}$ & This report ${ }^{9}$ \\
\hline $\begin{array}{l}\text { Spinner dolphin } \\
\text { (Stenella longirostris) }\end{array}$ & 1999 & $\begin{array}{l}\text { Makua, west coast of Oahu, } \\
\text { Hawaiian Islands, USA }\end{array}$ & Dewar (1999) 9, 12 \\
\hline \multirow[t]{2}{*}{$\begin{array}{l}\text { Pilot whale } \\
\text { (Globicephala spp.) }\end{array}$} & 1998-2002 & $\begin{array}{l}\text { Jeffreys Ledge, Massachusetts, } \\
\text { USA }\end{array}$ & Whale Center of New England (2002) ${ }^{13}$ \\
\hline & $\begin{array}{l}\text { Summer } \\
2002\end{array}$ & $\begin{array}{l}\text { Near Cape Cod, Massachusetts, } \\
\text { USA }\end{array}$ & Whale Center of New England (2002) 9,13 \\
\hline \multirow[t]{2}{*}{$\begin{array}{l}\text { Killer whale } \\
\text { (Orcinus orca) }\end{array}$} & $\begin{array}{l}27 \text { August } \\
1993\end{array}$ & $\begin{array}{l}\text { Southwest of St. Lawrence } \\
\text { Island, northern Bering Sea }\end{array}$ & Speckman and Sheffield (2001) \\
\hline & $\begin{array}{l}\text { Summer/Fall } \\
2000\end{array}$ & Aleutian Islands & Renner $(2000)^{9,14}$ \\
\hline $\begin{array}{l}\text { Bottlenose dolphin } \\
\text { (Tursiops truncatus) }\end{array}$ & $\begin{array}{l}\text { September } \\
2003\end{array}$ & Gulf of Mexico & This report ${ }^{9}$ \\
\hline
\end{tabular}

$\left({ }^{8}\right)$ Same individual in all the locations and years, $\left({ }^{9}\right)$ Verified with photographs; these are available for review by contacting the senior author of this paper, $\left({ }^{10}\right)$ Jones, K. (2003) Big news in Laguna Ojo de Liebre! Pure white whale calf. Available at: http://www.learner.org/jnorth/spring2003/ species/gwhale/Update031903.html\#Big. Accessed 18 November 2004, ( $\left.{ }^{11}\right)$ Cole, D. (2000) Heaviside's dolphin Cephalorhynchus heavisidii. Available at: http:/ /www.zestforbirds.co.za/heaviside2.html. Accessed 13 January 2004, $\left({ }^{12}\right)$ Dewar, S. (1999) White spinner dolphin. Available at: http:/ /www.stardewar.com/Encounters/ eagles.htm. Accessed 18 November 2004, $\left({ }^{13}\right)$ Whale Center of New England. (2002) Albino pilot whale. Available at: http:// www.whalecenter.org/ featuredwhalearchive.htm. Accessed 18 November 2004, $\left({ }^{14}\right)$ Renner, M. (2000) White orca. Available at: http://www.alaska.net/ hmoore/Aleutians.htm. Accessed 18 November 2004. 


\section{Acknowledgements}

We thank Captain Richard Rittenhouse, the captain and owner of the R/V Retriever, for his interest in the natural history of the Gulf of Mexico. Tom Jefferson verified our species identification of the common bottlenose dolphin. The albino spotted dolphin sighting was made during the SWFSC/NOAA Fisheries Stenella Abundance Research Project (http://swfsc.nmfs.noaa.gov/prd/PROJECTS/ star/default.htm). We thank Lisa T. Ballance, Chief Scientist for STAR, for facilitating the use of this record. We thank Todd Pusser and Ingrid Visser for their assistance in locating new records of anomalously white cetaceans. Star Dewar, Keith Jones, and Martin Renner provided additional cetacean records for inclusion here. Koen Van Waerebeek and Mônica Borobia improved this manuscript with their comments.

\section{References}

Fernandez, S. and Hohn., A.A. (1998) Age, growth, and calving season of bottlenose dolphins, Tursiops truncatus, off coastal Texas. Fishery Bulletin 96(2): 357-365.

Fertl, D. and Landry Jr., A.M. (1999) Sharksucker (Echeneis naucrates) on a bottlenose dolphin (Tursiops truncatus) and a review of other cetacean-remora associations. Marine Mammal Science 15(3): 859-863.

Fertl, D. and Landry Jr., A.M. (2002) Remoras. Pages 10131015 in Perrin, W.F., Würsig, B. and Thewissen, J.G.M. (Eds) Encyclopedia of Marine Mammals. Academic Press, San Diego, California.

Fertl, D. and Rosel, P. (2002) Albinism. Pages 16-18 in Perrin, W.F., Würsig, B. and Thewissen, J.G.M. (Eds) Encyclopedia of Marine Mammals. Academic Press, San Diego, California.

Fertl, D., Pusser, L.T. and Long, J.J. (1999) First record of an albino bottlenose dolphin (Tursiops truncatus) in the Gulf of Mexico, with a review of anomalously white cetaceans. Marine Mammal Science 15(1): 227-234.

Forestell, P.H., Patton, D.A., Hodda, P. and Kaufman, G.D. (2001) Observations of a hypo-pigmented humpback whale, Megaptera novaeangliae, off east coast Australia: 19912000. Memoirs of the Queensland Museum 47(2): 437-450.

Jones, S.C., III. (1988) Patterns of recent marine mammal strandings along the upper Texas coast. Cetus 7(1): 10-13.

Speckman, S.G. and Sheffield, G. (2001) First record of an anomalously white killer whale, Orcinus orca, near St. Lawrence Island, northern Bering Sea, Alaska. Canadian Field-Naturalist 115(3): 501-502.

Worthy, G. (1998) Patterns of bottlenose dolphin, Tursiops truncatus, strandings in Texas. Pages 47-55 in Zimmerman, R. (Ed.) Characteristics and causes of Texas marine strandings. U.S. Dep. Commer., NOAA Tech. Rep. NMFS 143. 